\title{
Can transformational managers control turnover intention?
}

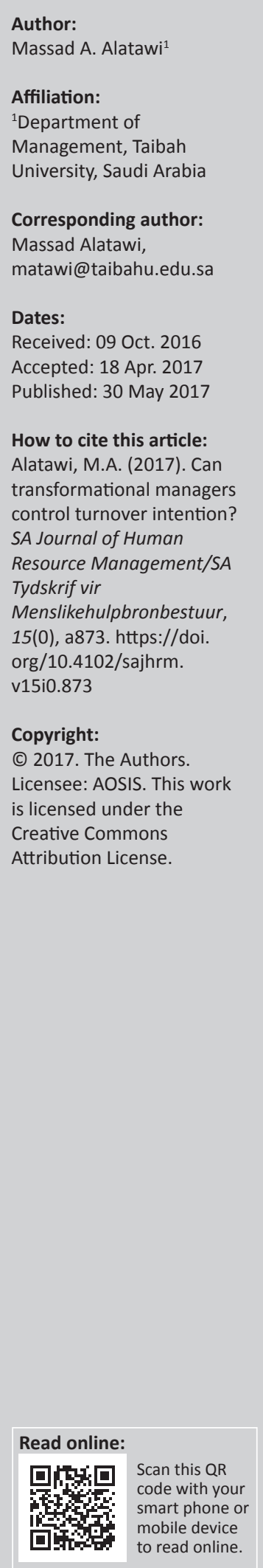

Orientation and research purpose: Employee turnover is a complex phenomenon that has negative consequences for organisations. The purpose of this study was to measure the correlation between transformational leadership style and turnover intention to control the employee turnover rate in organisations.

Research method: This study utilised a two-stage clustering method and web-based survey research with a correlational design to collect the data. A total of 356 responses were collected from 14 clusters in Southern California; however, the final selected data for analysis came from 210 subjects with a cluster-sampling design of $(14 \times 15)$.

Main findings and managerial implications: This study concluded that the transformational leadership style has a negative correlation with turnover intention. Managers who adopt this style of leadership can expect lower rates of turnover; thus, they can stay competitive in an unstable economy and achieve enhanced productivity, improved performance and reduction in expenses.

\section{Introduction}

Employee turnover is a complicated, continuous issue that affects the stability of the organisational climate, performance, productivity and the retention of the qualified employees. Abassi and Hollman (2000) represented employee turnover as the rotation of workers around the labour market; between organisations, jobs and occupations; and between the conditions of employment and unemployment. The expenses identified with employee turnover were evaluated to run from $25 \%$ to $500 \%$ of the annual compensation of a worker, with an average of $\$ 13996$ per worker. The high cost of employee turnover comprises human resources (HR) expenses such as recruiting, hiring and training costs and is connected with measures of productivity and performance of organisations (Ballinger, Craig, Cross \& Gray, 2011; O'Connell \& Mei-Chuan, 2007). Thus, controlling the employee turnover rate ought to be a priority amongst the most essential organisational goals.

Organisations must minimise expenses, maximise profits, expand productivity and deliberately plan to retain workers with the end goal to stay competitive in an unstable economy. Excessive employee turnover negatively influences organisations by delaying services and minimising profits as organisations attempt to recruit new workers as well as decreasing innovation as qualified workers leave. Most likely, excellent, talented workers are key employees. If they quit their jobs, then their organisations may not be able to finish key business transactions. To the contrary, employee turnover opens doors for newcomers who may carry with them experience, knowledge and innovation. Job changers may find a more advantageous workplace and better compensation (Fitz-Enz \& Davison, 2001; Lee, Hsu \& Lien, 2006; Mobley, 1982; Stovel \& Bontis, 2002). Numerous determinants affect the choice of workers to stay in or quit their jobs; nonetheless, managerial style is known to significantly affect their decisions.

Managerial style alludes to a general form of leadership used by a manager: transformational, transactional or laissez-faire (Rensselaer Polytechnic Institute, 2000). It acts as a principal stimulus for turnover intention inside of organisations. The backgrounds and experiences of managers affect the workers' intention to quit their jobs. Managers with a narrow-minded vision encounter a high employee turnover rate. They may wind up with an untalented workforce because of the loss of talented employees. Workers who stay may be disappointed, unfaithful and perform their undertakings inadequately. They may convey less customised services to clients. At the point when conditions seem to be intolerable, they may consider options and look to change their employment (Abassi \& Hollman, 2000; Lee et al., 2006; Mobley, 1982; Price, 2001; Stovel \& Bontis, 2002). Employee turnover is a complex issue to examine. 
Researchers examining employee turnover have experienced difficulty following the individuals who left their organisations; accordingly, this study measured the turnover intention rather than the actual turnover behaviour of employees. Turnover intention alludes to the extent to which employees plan to cease their membership with their organisations (Price, 2001). As it was stated earlier, turnover intention is a complex phenomenon that has negative consequences for organisations and needs close managerial attention. This study researched whether there was a connection between transformational leadership style and turnover intention to improve employee retention in Southern California. Subsequently, managers can adopt this managerial style with the aim to lower turnover rates amongst their workers, accordingly enhancing productivity, improving performance and reducing expenses. The purpose of this study was to measure the correlation between transformational leadership style and turnover intention to control the employee turnover rate in organisations.

Some studies (e.g. Griffith, 2004; Kleinman, 2004; Walumbwa \& Lawler, 2003; Walumbwa, Wang, Lawler \& Shi, 2004) have examined the relationship between transformational leadership style and turnover intention. Insufficient information is known about the impact of transformational leadership style on turnover intention (Griffith, 2004; Kleinman, 2004; Walumbwa \& Lawler, 2003; Walumbwa et al., 2004). In one study, Griffith (2004) revealed that school principal transformational leadership has an indirect negative impact, through job satisfaction, on school staff turnover. In addition to the effect measured in schools, Walumbwa and Lawler (2003) and Walumbwa et al. (2004) stated that transformational leadership style is negatively related to turnover intention in other work settings. Dissimilarly, Kleinman (2004) showed that transformational leadership style is not significantly linked to staff nurse turnover. Certainly, previous studies are contradictory in their conclusions regarding the association of transformational leadership style with turnover intention.

Besides the attempt to remove the contradiction in previous research regarding the linkage between transformational leadership style and turnover intention, one of the significances of this study was its diverse sample of organisations, because occupational diversity would increase the probability of class diversity, as suggested by Price (2001). Another significance was its focus on only one causal factor of turnover intention, namely managerial style, as suggested by Ongori (2007).

\section{Literature review}

Managerial style - the characteristic decisions, relationships and behaviours of managers - has a considerable effect on the turnover intention of employees (Lee et al., 2006; Price, 2001; Stovel \& Bontis, 2002). Dr Lindsay Ryan expressed that the primary reason labourers leave an occupation is that they have been assigned to work under ineffective supervisors (as cited in Lund, 2011). As indicated in an article in Accountancy
('Bad Month', 2009), more than half of employees in the banking industry quit their jobs because of ineffective administration, and around half would have been willing to take a pay cut to work with an effective manager. Changing the managerial style of insufficient managers could prompt better employee retention. Managers handle a scope of circumstances all through their day-to-day business schedules and perform numerous functions in their organisations. The basic functions of management include planning, organising, leading and controlling; in any case, these managerial functions no longer fit the 21st century. Employee retention is one of the top undertakings of managers and more essential today than at any other time (Daft, 2012; Lussier \& Achua, 2012). Managers ought to change their managerial style throughout today's period of nanotechnology.

The current literature has demonstrated that transformational leadership style is an effective managerial style in all kinds of organisations. The most practiced managerial style by effective managers is transformational. Transformational leadership style is not reserved for exceptional individuals with certain leadership qualities and capacities; anybody can be a transformational leader through education, desire and practice. Organisations can benefit by offering transformational leadership training to their supervisors. The transformational leadership style is an approach that changes workers to fulfil more than what is expected of them and is concerned with vision, staff development, supportive leadership, empowerment, innovative thinking, leading by example and charisma (Avolio, 2011; Carless, Wearing \& Mann, 2000; Lussier \& Achua, 2012; Northouse, 2010). These seven variables compose the dimensions of the Global Transformational Leadership (GTL) scale, which was developed by Carless et al. (2000; Table 1).

Transformational managers provide employees with a vision, act as coaches, provide a supportive climate, listen for employees' needs, recognise employees' achievements and delegate work to employees. They offer meaning and challenge to employees' work, involve employees in decisionmaking, encourage teamwork, support autonomy and stimulate excellent task performance. They inspire innovation and promote problem-solving in new ways. They behave as

TABLE 1: Dimensions of Global Transformational Leadership.

\begin{tabular}{|c|c|}
\hline Item & Dimension of GTL \\
\hline 1. Communicates a clear, positive vision of the future & Vision \\
\hline $\begin{array}{l}\text { 2. Treats staff as individuals, and supports and encourages } \\
\text { their development }\end{array}$ & Staff development \\
\hline 3. Gives encouragement and recognition to staff & Supportive leadership \\
\hline $\begin{array}{l}\text { 4. Fosters trust, involvement and cooperation amongst } \\
\text { team members }\end{array}$ & Empowerment \\
\hline $\begin{array}{l}\text { 5. Encourages thinking about problems in new ways and } \\
\text { questions assumptions }\end{array}$ & Innovative thinking \\
\hline $\begin{array}{l}\text { 6. Is clear about his or her values and practices what he } \\
\text { or she preaches }\end{array}$ & Lead by example \\
\hline $\begin{array}{l}\text { 7. Instils pride and respect in others and inspires me by } \\
\text { being highly competent }\end{array}$ & Charisma \\
\hline
\end{tabular}




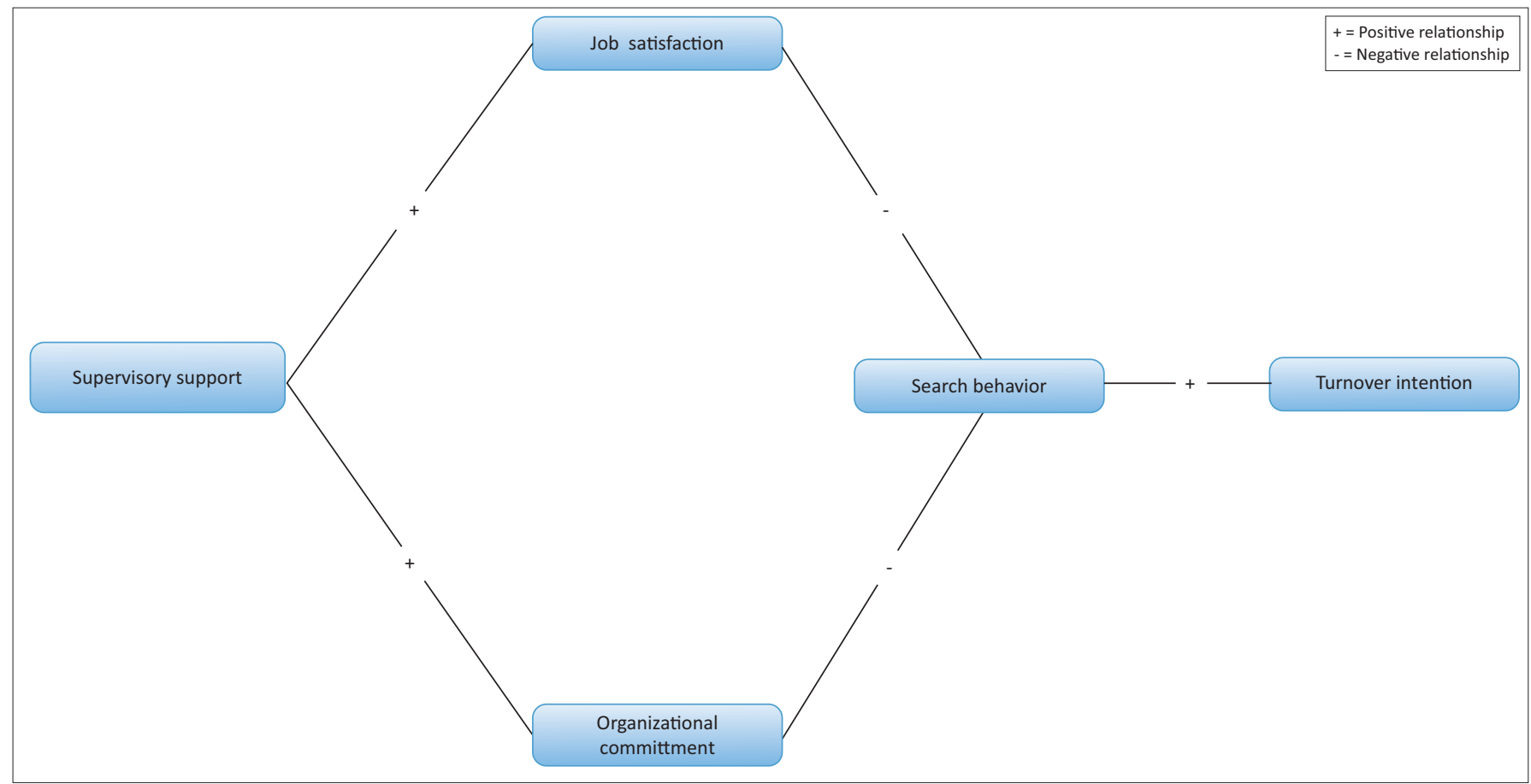

Source: Price, J.L. (2001). Reflections on the determinants of voluntary turnover. International Journal of Manpower, 22(7/8), 602. https://doi.org/10.1108/EUM0000000006233 FIGURE 1: A portion of the causal model of turnover.

models for employees and follow through with their promises. They demonstrate enthusiasm and can be trusted and respected to make good decisions for the organisation. One component that distinguishes transformational leadership style from other managerial styles is the inclusion of supportive leadership or supervisory support (Avolio, 2011; Carless et al., 2000; Northouse, 2010).

The causal model of turnover (Figure 1; introduced in 1981 by Price \& Mueller) shows supervisory support as a determinant of turnover intention. Supervisory support, meaning help with job-related problems, decreases turnover by its positive influence on both job satisfaction and organisational commitment. Job satisfaction and organisational commitment reduce turnover intention, whereas search behaviour increases turnover intention. For the purpose of this study, transformational leadership style was considered as equivalent to supervisory support. It influences turnover intention through the intervening variables of job satisfaction, organisational commitment and search behaviour (see Figure 1). It decreases turnover intention indirectly by means of a positive influence on job satisfaction and organisational commitment (Price, 2001).

The current literature confirms that transformational leadership style correlates positively with job satisfaction and organisational commitment. In addition, it shows that turnover intention correlates negatively with job satisfaction and organisational commitment. Several studies have demonstrated that workers want to stay with transformational managers. Satisfied workers are less inclined to quit their jobs. Labourers who are supervised by transformational managers are willing to stay with and are loyal to their organisations, even under tough circumstances. Transformational managers encourage employees to overcome difficulties and to be effective in their work, resulting in a decrease in the turnover intention rate (Avolio, 2011; Hetland \& Sandal, 2003; Judge \& Piccolo, 2004; Kearney, 2008; Lee et al., 2006; Price, 2001; Walumbwa et al., 2004).

\section{Method Data and sample}

This quantitative investigation of the anticipated relationship of a variable thought to be related to turnover intention used survey research with a correlational design and utilised a cluster-sampling method. The sample for this study comprised workers whose managers were members of the Professionals In Human Resources Association (PIHRA). PIHRA is an association that trains its members on perspectives of leadership and HR. It has roughly 3000 members who work in Southern California organisations from all ranges of industry inside of the most financially diverse territory in the nation (PIHRA, 2012). As proposed by Henderson and Sundaresan (1982) and the North Carolina Center for Public Health Preparedness (2012), this study used a two-stage cluster-sampling method. In the first stage, 150 managers (clusters) were chosen randomly, and the final response rate was 51\%; however, just 14 clusters were utilised because of the research criteria. ${ }^{1}$ In the second stage of cluster sampling, and particularly in December 2012, a total of 356 responses were collected from 14 clusters with a sample error of $5 \%$. Nevertheless, the final selected data for analysis came

1.Some of PIHRA members (clusters) were students and self-employed individuals; thus, the criterion for selecting the managers (clusters) was that each one had to have at least seven employees, and the criterion for selecting the employees (units) was that all the employees had to work full time. Although it was very difficult to secure permission from managers to study their subordinates in many organisations, the desire was to secure a sample size of at least 210 subjects with a $(30 \times 7)$ design. 
from 210 subjects with a cluster-sampling design of $(14 \times 15)$ because the process was controlled to limit over- or underrepresented clusters. Therefore, the participants were thought to be representative of all workers in Southern California. Confidentiality was maintained by all means and especially by ensuring information that could be tracked to an individual participant was not included in any reports of this article.

\section{Hypothesis}

The hypothesis $\left(\mathrm{H}_{1}\right)$ of this study was that the transformational leadership style of PIHRA members is negatively correlated with turnover intention of their subordinates; that is to say that transformational leadership style is predictive of lower levels of turnover intention.

\section{Variables and instrumentation}

This study measured the transformational leadership style, the independent variable, through the 7-item GTL scale using a 5-point Likert scale ranging from rarely or never to very frequently, if not always. Summing the scores of each item and then dividing the sum by seven resulted in a final score for transformational leadership style. A higher score showed that a PIHRA member often demonstrated transformational leadership style. The item 'How often have you seriously considered quitting your present job?' developed by Spector (1985) measured turnover intention, the dependent variable, using a 5-point Likert scale ranging from rarely or never to very frequently, if not always. A lower score of this item showed that a subordinate of a PIHRA member intended to keep his or her job. To analyse data, the major statistical tests were correlation and regression analytical techniques.

\section{Results}

Table 2 shows the aftereffects of the Spearman rho correlation analysis, which demonstrated that there was a moderate, negative significant correlation between transformational leadership style utilised by PIHRA members and the levels of turnover intention amongst their subordinates $\left(r_{\mathrm{s}}=-0.41\right.$, $p<0.01)$. Higher transformational leadership style scores $(M=4.42)$ were connected with lower levels of turnover intention $(M=1.09)$. Further calculation concluded that $17 \%$ of the variance in the levels of turnover intention amongst PIHRA subordinates was explained by transformational leadership style utilised by PIHRA members.

Table 2 shows characteristics of the Spearman rho correlation coefficient, which is a descriptive measure of the correlation of the transformational leadership style and turnover intention. The $t$-test value is a measure of the hypothesis that

TABLE 2: Correlations between transformational leadership style and turnover intention.

\begin{tabular}{lc}
\hline Analysis & Score \\
\hline Spearman's rho & -0.41 \\
$t$-test value for hypothesis $r=0$ & -6.40 \\
$p$-level & $<0.01$ \\
\hline
\end{tabular}

the correlation between transformational leadership style and turnover intention found in the study sample exists in the population comprising subordinates of all PIHRA members. The hypothesis $\left(\mathrm{H}_{1}\right)$ was that the two variables are correlated; the null hypothesis $\left(\mathrm{H}_{0}\right)$ was that the two variables are not correlated. With 208 degrees of freedom $[(n-2)=(210-2)=208]$, testing for significance at the 0.01 level, the critical values of \pm 2.576 and a calculated $t$-test value of -6.40 , the null hypothesis was rejected. The observed value of $r_{\mathrm{s}}$ is large enough to indicate a statistically significant correlation between transformational leadership style and turnover intention. This finding is corroborated by the calculated $p$-level of less than 0.01 .

The outcomes of bivariate linear regression analyses are demonstrated in Table 3 and indicate that the transformational leadership style used by PIHRA members explained $17 \%$ of the variance $\left(R^{2}=0.17, t=-9.45, p<0.01\right)$ in the levels of turnover intention amongst their subordinates. As explained in the above paragraph, the $t$-value of less than -2.576 and the calculated $p<0.01$ showed a regression model with statistically significant predictive power. The outcomes also suggested a regression model in which a one-percentagepoint increase in transformational leadership style used by PIHRA members leads to a $0.32 \%$ reduction in turnover intention levels of their subordinates $(b=-0.32, p<0.01)$.

\section{Discussion}

This study revealed that the transformational leadership style of PIHRA members is negatively linked to turnover intention of their subordinates. This specific finding is not the same as that of Kleinman (2004), who found that transformational leadership style is not correlated with staff nurse turnover. Notwithstanding, this study's finding is in line with what Griffith (2004), Walumbwa and Lawler (2003) and Walumbwa et al. (2004) concluded about transformational leadership style and its negative correlation with turnover intention. This study's result removes the contradiction in previous research and creates a clearer context for the significance of transformational leadership style and its linkage to controlling employee turnover rate in organisations.

This study contributed that the transformational leadership style of PIHRA members is negatively correlated with turnover intention of their subordinates; that is to say that transformational leadership style is predictive of lower levels of turnover intention. The after-effect of this study can be generalised to most of the organisations in Southern California. This study adds insight to the body of knowledge concerning transformational leadership style and its significance to the retention of employees. It recognises the

TABLE 3: Linear regression of transformational leadership style and turnover intention.

\begin{tabular}{lcccc}
\hline Linear regression & Coefficients $(\boldsymbol{b})$ & Standard error & $\boldsymbol{t}$ & $\boldsymbol{p}$ \\
\hline Intercept & 2.51 & 0.15 & 16.59 & $<0.01$ \\
$\begin{array}{l}\text { Transformational } \\
\text { leadership style }\end{array}$ & -0.32 & 0.03 & -9.45 & $<0.01$ \\
\hline
\end{tabular}


negative relationship between transformational leadership style and turnover intention; hence, managers can apply transformational leadership as their managerial style with the expectation of a lower turnover rate. Consequently, they can stay competitive in an unstable economy and achieve enhanced productivity, improved performance and reduction in expenses.

This study revealed that supervisors with a transformational leadership style could be recruited. It found that the mean score of transformational leadership style was high $(M=4.42)$, showing that the participants' managers every now and again apply transformational leadership style in their organisations and that their enrolment in PIHRA has paid off. This outcome is in accordance with the current literature that shows transformational leadership is not reserved for individuals with exceptional attributes and capacities; rather, anyone can be transformational (Avolio, 2011; Carless et al., 2000; Lussier \& Achua, 2012; Northouse, 2010). Managers can be transformational by (1) planning for the future, (2) coaching workers, (3) supporting workers to develop in their jobs and acknowledging their effort and achievement, (4) including employees in the decisionmaking process, (5) inspiring innovation, (6) being honest and following the rules and (7) acting as change specialists. Finally, they must practice regularly because mastering transformational leadership style takes time, exertion and commitment.

This study inferred that transformational leadership style is an effective managerial style. Managers should change their managerial style for the high-tech business world. They ought to enhance their transformational leadership abilities and skills. It is recommended that managers attend seminars, webinars or workshops, or join associations that teach and train their members on concepts of transformational leadership style. When recruiting new managers, HR managers ought to select transformational candidates keeping in mind the end goal to profit by enhancing the retention of employees. Organisations should train their current managers on transformational leadership style to improve the organisational climate. Business pioneers must be transformational; otherwise, the small-business labourers may leave, and as an outcome, the business may shut down.

The literature showed that a disagreeable managerial style is perhaps one of the reasons for the turnover intention phenomenon. However, if ineffective managers drive workers to intend to quit their jobs, it does not imply that effective managers drive workers to keep their jobs. Consequently, a suggested study would comprise experimental research to explore the cause-effect relationship of transformational leadership style and employee retention. The low mean score of intention to quit $(M=1.09)$ shows that the state of the economy (whilst conducting this research in 2012) may have impacted the members' choices about keeping their occupations and, consequently, may have affected the correlation measured between transformational leadership style and turnover intention. Further research is recommended to duplicate this study when the economy has recovered. Future studies concerning transformational leadership ought to utilise the GTL scale because it is reliable, valid, short and practical.

Finally, future research is suggested to replicate this study and look at a nondemocratic country to see if similar conclusions would be found about the relationship between transformational leadership style and turnover intention. This study has been carried out in the United States; therefore, it is reasonable to suppose that democratic, capitalistic countries are the areas to which the outcomes of this study apply. Yet, it would be interesting to see whether or not similar findings would be found in nondemocratic countries.

\section{Conclusion}

To conclude, this study made a contribution to the knowledge on the significance of transformational leadership style to the employee retention. It found a negative correlation between transformational leadership style and turnover intention. It found that a slight increase in transformational leadership style leads to a decrease in the levels of turnover intention among employees. Hiring or training transformational managers supports essentially control turnover. Managers should obtain transformational leadership behaviors and skills in order to reduce the turnover intention among their employees. Everyone can be transformational by practicing the behaviours and skills of this style.

\section{Acknowledgements}

The author thanks Dr Casey Goodall for comments that greatly improved the manuscript. Without Dr Goodall's thoughts and ideas, this manuscript would not appear in its great shape as it does.

\section{Competing interests}

The author declares that he has no financial or personal relationships that may have inappropriately influenced him in writing this article.

\section{References}

Abassi, S.M., \& Hollman, K.W. (2000). Turnover: The real bottom line. Public Personnel Management, 29(3), 333-342. https://doi.org/10.1177/00910260000 2900303

Avolio, B.J. (2011). Full range leadership development. (2nd edn.). Thousand Oaks, CA Sage.

Bad month: British managers. (2009). Accountancy, 144(1396), 12.

Ballinger, G., Craig, E., Cross, R., \& Gray, P. (2011). A stitch in time saves nine: Leveraging networks to reduce the costs of turnover. California Management Review, 53(4), 111-133. https://doi.org/10.1525/cmr.2011.53.4.111

Carless, S.A., Wearing, A.J., \& Mann, L. (2000). A short measure of transformational leadership. Journal of Business and Psychology, 14(3), 389-405. https://doi. org/10.1023/A:1022991115523

Daft, R.L. (2012). Management. (10th edn.). Mason, OH: South-Western.

Fitz-Enz, J., \& Davison, B. (2001). How to measure human resource management. (3rd edn.). New York: McGraw-Hill.

Griffith, J. (2004). Relation of principal transformational leadership to school staff job satisfaction, staff turnover, and school performance. Journal of Educational Administration, 42(3), 333-356. https://doi.org/10.1108/09578230410534667 
Henderson, R.H., \& Sundaresan, T. (1982). Cluster sampling to assess immunization coverage: A review of experience with a simplified sampling method. Bulletin of the World Health Organization, 60(2), 253-260.

Hetland, H., \& Sandal, G.M. (2003). Transformational leadership in Norway: Outcomes and personality correlates. European Journal of Work \& Organizational Psychology, 12(2), 147. https://doi.org/10.1080/13594320344000057

Judge, T.A., \& Piccolo, R.F. (2004). Transformational and transactional leadership: A meta-analytic test of their relative validity. Journal of Applied Psychology, 89(5), 755-768. https://doi.org/10.1037/0021-9010.89.5.755

Kearney, E. (2008). Age differences between leader and followers as a moderator of the relationship between transformational leadership and team performance. Journal of Occupational \& Organizational Psychology, 81(4), 803-811. https://doi. org/10.1348/096317907X256717

Kleinman, C. (2004). The relationship between managerial leadership behaviors and staff nurse retention. Hospital Topics, 82(4), 2-9. https://doi.org/10.3200/HTPS. staff nurse
$82.4 .2-9$

Lee, C., Hsu, M., \& Lien, N. (2006). The impacts of benefit plans on employee turnover: A firm-level analysis approach on Taiwanese manufacturing industry. International Journal of Human Resource Management, 17(11), 1951-1975. https://doi. org/10.1080/09585190601000154

Lund, M. (2011, August). How bad managers lose good staff. The Courier Mail (Brisbane), p. 4.

Lussier, R.N., \& Achua, C.F. (2012). Leadership: Theory, application, and skill development. (5th edn.). Cincinnati, $\mathrm{OH}$ : South-Western College.

Mobley, W.H. (1982). Employee turnover: Causes, consequences, and control. Reading, MA: Addison-Wesley.

North Carolina Center for Public Health Preparedness. (2012). Two-stage cluster sampling: General guidance for use in public health assessments. Retrieved January 06, 2012, from http://cphp.sph.unc.edu/PHRST5/TwoStageSampling.pdf

Northouse, P.G. (2010). Leadership theory and practice. (5th edn.). Thousand Oaks, CA: Sage.
O'Connell, M., \& Mei-Chuan, K. (2007). The cost of employee turnover. Industrial Management, 49(1), 14-19.

Ongori, H. (2007). A review of the literature on employee turnover. African Journal of Business Management, 49-54. Retrieved June 13, 2011, from http://www. academicjournals.org/AJBM/pdf/pdf2007/jun/ongori.pdf

Price, J.L. (2001). Reflections on the determinants of voluntary turnover. International Journal of Manpower, 22(7/8), 600-624. https://doi.org/10.1108/EUM0000 000006233

Price, J.L., \& Mueller, C.W. (1981). A causal model of turnover for nurses. Academy of Management Journal, 24(3), 543-565. https://doi.org/10.2307/255574

Professionals In Human Resources Association (PIHRA). (2012). About PIHRA: Facts. Retrieved January 05, 2012, from http://pihra.org/displaycommon.cfm?an= $1 \&$ subarticlenbr=194

Rensselaer Polytechnic Institute. (2000, July 17). Management styles. Retrieved December 12, 2011, from http://www.rpi.edu/dept/advising/free_enterprise/ business_structures/management_styles.htm

Spector, P.E. (1985). Measurement of human service staff satisfaction: Development of the job satisfaction survey. American Journal of Community Psychology, 13(6), 693-713. https://doi.org/10.1007/BF00929796

Stovel, M., \& Bontis, N. (2002). Voluntary turnover: Knowledge management friend or foe? Journal of Intellectual Capital, 3(3), 303-322. https://doi.org/10.1108/ 14691930210435633

Walumbwa, F.O., \& Lawler, J.J. (2003). Building effective organizations: Transformational leadership, collectivist orientation, work-related attitudes, and withdrawal behaviors in three emerging economies. International Journal of Human Resource Management, 14(7), 1083-1101. https://doi.org/10.1080/ 0958519032000114219

Walumbwa, F.O., Wang, P., Lawler, J.J., \& Shi, K. (2004). The role of collective efficacy in the relations between transformational leadership and work outcomes. Journal of Occupational \& Organizational Psychology, 77(4), 515-530. https://doi.org/10. $1348 / 0963179042596441$ 